Anna Szelagowska*

\title{
RYNEK POŻYCZEK POZABANKOWYCH W POLSCE W ŚWIETLE POLITYKI NISKICH STÓP PROCENTOWYCH BANKU CENTRALNEGO
}

\section{Wprowadzenie}

Dostęp do podstawowych usług finansowych jest niezbędnym warunkiem uczestnictwa w życiu społecznym i gospodarczym kraju. Dynamiczny rozwój rynków finansowych, odgrywających kluczową rolę w dystrybucji bogactwa, prowadzi do wzrostu rozwarstwienia społecznego. Narastające dysproporcje w poziomie zamożności między najbogatszymi a najbiedniejszymi mieszkańcami danego kraju determinują stopień wykluczenia finansowego. Banki, skoncentrowane na maksymalizacji zysków, odwróciły się od najbiedniejszej grupy niedochodowych klientów. Sytuację tę wykorzystują z powodzeniem firmy pożyczkowe, oferując natychmiastowy pieniądz po cenie wielokrotnie wyższej niż cena pieniądza bankowego ${ }^{1}$. Dzieje się tak, pomimo istniejącego $\mathrm{w}$ wielu krajach, $\mathrm{w}$ tym także w Polsce, limitu maksymalnego oprocentowania kredytów i pożyczek. Nawet realizowana w ostatnich latach polityka niskich (a w niektórych krajach - zerowych) stóp procentowych nie jest barierą dla dynamicznego rozwoju firm pożyczkowych. Niniejszy artykuł ma dać odpowiedź na problem badawczy sformułowany w postaci następującego pytania: czy, i jeśli tak, to dlaczego, pomimo najniższych w historii podstawowych stóp procentowych w Polsce oraz nieporównywalnie wysokich łącznych kosztów pożyczek pozabankowych rynek tzw. chwilówek wygrywa konkurencję z sektorem bankowym? W świetle powyższego problemu weryfikacji poddano następującą hipotezę badawczą: brak nadzoru nad firmami pożyczkowymi działającymi na terenie Polski prowadzi do lichwiarskiego wyzysku tych, którzy zostali wykluczeni przez banki, skutkując wpadaniem przez znaczną część tej grupy społeczeństwa w spiralę zadłużenia. Rozwiązanie

* Szkoła Główna Handlowa w Warszawie, Kolegium Nauk o Przedsiębiorstwie.

1 Przykładowo, wydanie decyzji o udzieleniu pożyczki online przez Kreditech Polska wynosi średnio 42 sekundy. 
tak sformułowanego zagadnienia badawczego zostało zrealizowane poprzez studia literaturowe, analizę, syntezę i krytykę dostępnych materiałów źródłowych, których charakterystyka była podstawą do wyciągnięcia wniosków końcowych i weryfikacji hipotezy badawczej.

\section{Wykluczenie finansowe a wykluczenie społeczne}

Podstawowym celem współczesnych koncepcji rozwoju społeczno-ekonomicznego jest poprawa jakości życia oraz ograniczenie nadmiernych różnic w sytuacji finansowej i społecznej różnych grup społecznych. Wyrównywanie dysproporcji w szeroko rozumianym poziomie życia i eliminowanie zjawisk związanych z wykluczeniem społecznym stanowi także priorytet polityki społecznej Unii Europejskiej w ramach realizowanej Strategii Europa 2020. W dokumencie tym zapisano, że do 2020 r. liczba osób ubogich lub wykluczonych społecznie ma się zmniejszyć w UE o $20 \mathrm{mln}$ (czyli z poziomu 115,6 mln w 2008 r. do 95,6 mln osób w 2020 r.). Według danych Komisji Europejskiej w 2011 r. 24,2\% populacji UE 27 było dotkniętych ubóstwem lub wykluczeniem społecznym, z czego największy poziom ubóstwa i wykluczenia społecznego wyrażony w wielkościach absolutnych odnotowano we Włoszech (17,1 mln osób), w Niemczech (16 mln osób), w Wielkiej Brytanii (14 mln osób), w Hiszpanii (12,3 mln osób), we Francji (11,8 mln osób) i w Polsce (10,1 mln osób)². Powszechnie przyjmuje się, że wykluczenie finansowe jest pochodną wykluczenia społecznego. Oba te pojęcia należą do zjawisk złożonych.

W międzynarodowych statystykach jednym ze wskaźników³ odzwierciedlających stopień wykluczenia społecznego jest wielowymiarowy wskaźnik pogłębionej deprywacji materialnej, na który składa się brak możliwości zaspokojenia co najmniej czterech $\mathrm{z}$ dziewięciu potrzeb: opłacenie raz $\mathrm{w}$ roku dla gospodarstwa domowego tygodniowego urlopu poza domem; jedzenie co drugi dzień posiłku, w skład którego wchodzi mięso, kurczak, ryby (lub wegetariański odpowiednik); ogrzewanie mieszkania odpowiednio do potrzeb; natychmiastowe pokrycie niespodziewanego wydatku; terminowe regulowanie opłat związanych z utrzymaniem mieszkania

\footnotetext{
2 European Commission, European Social Statistics, 2013 edition, Eurostat pocketbooks, s. 172. http:// ec.europa.eu/eurostat/documents/3930297/5968986/KS-FP-13-001-EN.PDF/6952d836-7125-4ff5-a1536ab1778bd4da, dostęp 15.03.2015.

3 W 2001 r. stworzono dla wszystkich państw UE listę 18 podstawowych wskaźników ubóstwa i wykluczenia społecznego, która jest uaktualniana i uzupełniana przez Podgrupę Wskaźnikową (Indicators Sub-Group) Komitetu ds. Zabezpieczenia Społecznego (Social Protection Commitee - SPC).
} 
i płaceniem czynszu, terminowe regulowanie rat kredytów i pożyczek; kupno telewizora kolorowego; kupno samochodu; kupno pralki; kupno telefonu (stacjonarnego lub komórkowego). Z danych Eurostatu wynika, że według stanu na koniec $2011 \mathrm{r}$. 8,8\% populacji UE 27 było dotkniętych pogłębioną deprywacją materialną, z czego w największym stopniu Bułgaria (43,6\%), Łotwa (31,4\%), Rumunia (29,4\%), Litwa $(18,5 \%)$, Grecja $(15,2 \%)$ i Polska $(13 \%)^{4}$. Drugim wskaźnikiem pokazującym problem ubóstwa i wykluczenia społecznego jest ubóstwo relatywne, dotyczące osób, których dochód jest mniejszy niż $60 \%$ mediany dla danego kraju. Wskaźnik ten jest powiązany z dystrybucją dochodu i uwzględnia wszystkie źródła dochodów pieniężnych. Według danych Komisji Europejskiej na koniec 2011 r. ubóstwem relatywnym dotkniętych było $16,9 \%$ populacji UE 27 , z czego najwyższy wskaźnik odnotowano w Bułgarii (22,3\%), Rumunii (22,2\%), Hiszpanii (21,8\%), Grecji (21,4\%), na Litwie (20,0\%), we Włoszech $(19,6)$, na Łotwie $(19,1 \%)$, w Portugalii $(18,0 \%)$ oraz w Polsce $(17,7 \%)^{5}$. Kolejnym wyznacznikiem ubóstwa i wykluczenia społecznego jest tzw. bardzo mała intensywność pracy, mierzona poprzez udział osób w wieku produkcyjnym w gospodarstwie domowym, które pracowały nie więcej niż 20\% pełnego rocznego czasu pracy. Średnia dla UE 27 w 2011 r. wynosiła 10\%. W tym wypadku wskaźnik kształtował się od 5,8\% dla Luksemburga do 22,9\% w Grecji. W Polsce wskaźnik ten wyniósł $6,9 \%{ }^{6}$. Wnioski wypływające $\mathrm{z}$ analizy danych historycznych wskazują, że realizacja celu zmniejszenia ubóstwa i wykluczenia społecznego zapisanego w Strategii Europa 2020 oddala się ze względu na wzrost tej liczby w latach 2008-2012 w UE 27 o 8,7 mln osób. To z kolei prowadzi do dalszego wzrostu wykluczenia finansowego. Sytuację tę wykorzystują z powodzeniem prężnie rozwijające się firmy pożyczkowe, działające poza sektorem bankowym ${ }^{7}$.

Poszukiwanie związków przyczynowo-skutkowych między wykluczeniem finansowym a wykluczeniem społecznym znalazło odzwierciedlenie w wielu opracowaniach naukowo-badawczych powstałych na gruncie neoklasycznej teorii ekonomii, teorii ekonomii behawioralnej, teorii ekonomii instytucjonalnej i teorii ekonomii politycznej ${ }^{8}$. Przegląd światowej literatury wskazuje na wieloaspektowe podejście

4 European Commission, European Social Statistics..., op.cit., s. 188. Z kolei w Luksemburgu i w Szwecji deprywacją materialną było dotknięte tylko 1,2\% populacji.

5 Ibidem, s. 173. Najniższy wskaźnik relatywnego ubóstwa odnotowano w Czechach (9,8\%).

6 Ibidem, s. 173.

7 Przykładowo w Wielkiej Brytanii wartość rynku wysokooprocentowanych, pozabankowych pożyczek podwaja się każdego roku. Szerzej na ten temat: http://www.consumeraffairs.org.uk/loans/payday-loan/guides/payday-loan-market-uk-compares-nations, dostęp 10.03.2015.

8 Zob. T. Panek, J. Zwierzchowski, Porównawcza analiza sfery ubóstwa $w$ krajach UE w ujęciu regionalnym, „Zeszyty Naukowe Instytutu Statystyki i Demografii SGH” 2013, nr 35; T. Panek, Ubóstwo, wykluczenie społeczne i nierówności. Teoria i praktyka pomiaru, Oficyna Wydawnicza SGH, Warszawa 2011; R. Lister, Bieda, Sic, Warszawa 2007; Ubóstwo i wykluczenie społeczne - perspektywa poznawcza, red. R. Szarfenberg, 
do zdefiniowania pojęcia wykluczenia finansowego. W szerokim znaczeniu, na co wskazuje L. Anderloni, wykluczeniem finansowym nazywa się trudności, jakich doświadczają osoby o niskich dochodach i znajdujące się w niekorzystnej sytuacji społecznej w korzystaniu z usług finansowych, które są im potrzebne (np. posiadanie konta i możliwości dokonywania rozliczeń bezgotówkowych, dostęp do kredytu lub pożyczki o „rozsądnym” poziomie oprocentowania czy też budowanie nawet niewielkich oszczędności, z uwzględnieniem niestabilnej sytuacji zawodowej) $)^{9}$. Wykluczenie finansowe jest jedną z form wykluczenia społecznego. Odnosi się ono do niewydolności systemu bankowego w zakresie oferowania pełnej gamy usług depozytowych i kredytowych po przystępnych cenach dla wszystkich gospodarstw domowych lub podmiotów gospodarczych. Jak zauważa G. Dymski, systematyczne ograniczanie dostępu tych grup do usług rynku finansowego zagraża ich zdolności do pełnego uczestnictwa w życiu gospodarczym i w akumulacji majątku ${ }^{10}$. W szerokim tego słowa znaczeniu wykluczenie finansowe należy traktować jako niezdolność określonej grupy społecznej do korzystania z podstawowych usług finansowych. Ten swoisty ostracyzm finansowy dotyka głównie gospodarstw domowych o niskich dochodach, które nie są atrakcyjne z punktu widzenia banków nastawionych na maksymalizację zysków. Z mikroekonomicznego punktu widzenia wykluczenie finansowe jest sytuacją, w której gospodarstwo domowe napotyka na obiektywne i subiektywne przeszkody w dostępie do rynku usług finansowych, uniemożliwiające mu życie w godnych warunkach. Proces minimalizacji wykluczenia finansowego ma na celu zapobieganie ograniczaniu pewnej grupy społecznej w dostępie do systemu finansowego. Charakterystyczną cechą systemu finansowego, na co zwracają uwagę A. Leyshon i N. Thrift, jest jego nieodłączna skłonność do dyskryminowania biednych i pokrzywdzonych przez los grup społecznych ${ }^{11}$. Innymi

C. Żołędowski, M. Theiss, Dom Wydawniczy ELIPSA, Warszawa 2010; B. Szopa, A. Szopa, Wykluczenie finansowe a wykluczenie społeczne, „Zeszyty Naukowe Polskiego Towarzystwa Ekonomicznego” 2011, nr 11; Edukacja i świadomość finansowa, Oficyna Wydawnicza SGH, red. M. Iwanicz-Drozdowska, Warszawa 2011; Financial Services Provision and Prevention of Financial Exclusion, European Commission, Brussels May 2008; P. Lenton, P. Mosley, Financial Exclusion and the Poverty Trap. Overcoming deprivation in the inner city, Routledge 2012; R. Awal, Financial exclusion and Microcredit, Lambert Academic Publishing, 2011; C. Santiago, E.P.M. Gardener, P. Molyneux, Financial Exclusion, Palgrave Macmillan, 2005; M. Marcinkowska, I. Kuchciak, M. Świeszczak, K. Świeszczak, Edukacja finansowa i inkluzja bankowa w realizacjach koncepcji silver economy, Wydawnictwo Uniwersytettu Łódzkiego, Łódź 2014.

9 L. Anderloni, Access to Bank Account and Payment Services, w: New Frontiers in Banking Services. Emerging Needs and Tailored Products for Untapped Markets, red. L. Anderloni, M.D. Braga, E.M. Carluccio, Springer - Verlag, Berlin-Heidelberg 2007, s. 7.

10 G. Dymski, Financial Globalization, Social Exclusion and Financial Crisis, "International Review of Applied Economics" 2005, Vol. 19, No. 4, s. 440.

11 A. Leyshon, N. Thrift, Money/Space. Geographies of Monetary Transformation, Routledge, London 1995, s. 228. 
słowy, im biedniejsze są jednostki, tym większe prawdopodobieństwo wykluczenia ich z systemu finansowego i tym większe szanse na nielegalny rozwój szarej strefy niekontrolowanych pożyczek. Rozwój pozabankowego rynku wysokooprocentowanych pożyczek, działających poza nadzorem finansowym, jest jednym z czynników destabilizujących system finansowy. Jak zauważa H. Żukowska, potrzebny jest wzrost świadomości wagi stabilności finansowej, traktowanie jej jako dobra publicznego i jednocześnie dostrzeganie jej permanentnego zagrożenia na skutek oddziaływania wielu destabilizatorów ${ }^{12}$.

\section{Rozwój rynku firm pożyczkowych w Polsce}

Pierwotnie wykluczenie finansowe było przypisane ograniczeniom w dostępie klientów do oddziałów bankowych, a następnie także do głównego nurtu usług finansowych banków (tzw. usług mainstreamowych). W tym kontekście społeczeństwo można podzielić na trzy grupy: całkowicie pozbawionych dostępu do usług bankowych (unbanked), częściowo pozbawionych dostępu do usług bankowych (marginally banked) oraz w pełni korzystających z usług bankowych (fully banked $)^{13}$. Podział ten wiąże się m.in. $\mathrm{z}$ ubankowieniem społeczeństwa. $\mathrm{Z}$ badań przeprowadzonych w 2012 r. przez instytut $\mathrm{PBS}^{14}$ wynikało, że 77\% Polaków powyżej 15 roku życia posiadało rachunek bankowy lub konto w SKOK. Analogiczne dane uzyskano w badaniu przeprowadzonym w 2013 r. przez NBP, z którego wynikało, że 23\% respondentów nie posiada rachunku w banku lub konta w SKOK ${ }^{15}$. Z badań Banku Światowego, przeprowadzonych w 2012 r., dotyczących poziomu ubankowienia w UE wynikało, że konta nie posiadało $30 \%$ Polaków powyżej 15 roku życia. Polska znalazła się na trzecim miejscu od końca w UE, wyprzedzając jedynie Bułgarię i Rumunię. Średnia unijna pod względem nieubankowienia wynosi 14\%. Według danych ZBP w 2013 r.

${ }^{12}$ H. Żukowska, Identyfikacja czynników destabilizujących systemy finansowe, w: Eseje o stabilności finansowej. Księga jubileuszowa. 45 lat pracy naukowej prof. zw. dr. hab. Bogusława Pietrzaka, red. A. Alińska, CeDeWu, Warszawa 2012, s. 404.

${ }^{13}$ L. McKean, S. Lessem, E. Bax, Money Management by Low-income Households: Earning, Spending, Saving, and Accessing Financial Services, Center for Impact Research, August 2005, s. 1; http://www.impactresearch.org/documents/FirstAccountsExecutiveSummary.pdf

14 Badanie PBS Loyalty Benchmark, zrealizowane w I połowie 2012 r. na reprezentatywnej próbie Polaków w wieku 15+, n=5391; http://pbs.pl/x.php/1,1072/Wskaznik-ubankowienia-Polakow-zwalnia.html, dostęp 10.03.2015.

${ }^{15}$ Zob. Zwyczaje płatnicze Polaków, Narodowy Bank Polski, Warszawa 2013. 
19\% Polaków nie posiadało rachunku w banku ${ }^{16}$. Problem dotyczy też tych klientów banków, którzy posiadając rachunek bankowy, nie mają regularnych wpływów i tym samym nie mają zdolności kredytowej, co wyklucza ich finansowo ze społeczeństwa. Zarówno dla tych gospodarstw domowych, które nie posiadają rachunku bankowego, jak i dla tych, których nie stać na zaspokajanie podstawowych potrzeb finansowych, alternatywą są firmy pożyczkowe. Należy jednak dodać, że część firm pożyczkowych wymaga od klientów posiadania rachunku bankowego w jednym z banków krajowych i dokonania przelewu weryfikacyjnego (z reguły to symboliczny 1 grosz) przed udzieleniem pożyczki. W pozostałych wypadkach wystarczy dowód osobisty, telefon komórkowy i adres e-mail (w wypadku pożyczek udzielanych online).

W Polsce pozabankowe instytucje pożyczkowe działają na podstawie art. 6 ust. 1 ustawy z dnia 2 lipca 2004 r. O swobodzie działalności gospodarczej (tekst jedn. Dz. U. 2013, poz. 672 z późn. zm.). Firmy pożyczkowe są zobowiązane do przestrzegania przepisów ustawy z dnia 12 maja 2011 r. O kredycie konsumenckim (tekst jedn. Dz. U. 2014, poz. 1497). Ustawa ta jest implementacją dyrektywy Parlamentu Europejskiego i Rady 2008/48/WE z dnia 23 kwietnia 2008 r. W sprawie umów o kredyt konsumencki ${ }^{17}$. Podmioty te muszą również prowadzić działalność zgodnie z przepisami ustawy z dnia 23 kwietnia 1964 r. - Kodeks cywilny (tekst jedn. Dz. U. 2014, poz. 121). Firmy pożyczkowe nie mają obowiązku uzyskania zezwolenia na prowadzenie licencjonowanej działalności pożyczkowej. Nie podlegają tym samym nadzorowi finansowemu oraz nie podlegają systemowi gwarantowania depozytów. Założenie firmy pożyczkowej w formie jednoosobowej działalności gospodarczej wymaga tylko złożenia w urzędzie miasta wniosku o wpis do CEIDG. W Polsce nadzór nad wykonywaniem przepisów ustawy O kredycie konsumenckim prowadzi Urząd Ochrony Konkurencji i Konsumentów, który bada praktyki pozabankowych podmiotów pożyczkowych pod względem naruszenia ustawy z dnia 16 lutego 2007 r. O ochronie konkurencji i konsumentów (tekst jedn. Dz. U. 2015, poz. 184) oraz sprawdza, czy oferowane przez te przedsiębiorstwa wzorce umowne nie zawierają niedozwolonych klauzul. Firmy pożyczkowe nie są także zobowiązane do podawania informacji o skali swojej działalności, czyli liczby i wartości udzielanych pożyczek, co uniemożliwia oszacowanie wielkości całego rynku pozabankowych firm pożyczkowych w Polsce. Z danych Związku Firm Pożyczkowych wynika, że w Polsce w 2014 r. działało ok. 100 firm pożyczkowych, których działalność obejmowała swoim zasięgiem

${ }_{16}$ Związek Banków Polskich, Polityka kredytowa w Polsce i w UE, lipiec 2014, s. 7; http://zbp.pl/public/ repozytorium/wydarzenia/images/lipiec_2014/Konferencja_Prasowa/ZBP_Raport_polityka_kredytowa_w_ Polsce_i_UE.pdf, dostęp 10.03.2015.

17 Directive 2008/48/EC of the European Parliament and of the Council of 23 April 2008 on credit agreements for consumers and repealing Council Directive 87/102/EEC. L133/66. 
obszar całego kraju, oraz ok. 1000 lokalnych firm pożyczkowych zarejestrowanych $\mathrm{w}$ formie jednoosobowej działalności gospodarczej ${ }^{18}$.

Z badań opublikowanych w Diagnozie Społecznej 2013 wynika, że 0,7\% łącznej wartości zobowiązań pochodzi z pożyczek pozabankowych, co pozwala oszacować ten rynek w skali 3-4 mld PLN ${ }^{19}$. Do podobnych wniosków doszła KNF, publikując wyniki z 2013 r., które wskazują, że całkowita skala działania firm pożyczkowych w Polsce wyniosła 3-4 mld PLN ${ }^{20}$. Według danych Związku Firm Pożyczkowych, w 2014 r. Polacy zadłużyli się w firmach pożyczkowych na łączną kwotę 4,1 mld PLN ${ }^{21}$. Dla porównania, wartość kredytów konsumpcyjnych udzielonych przez banki spółdzielcze osobom prywatnym wyniosła na koniec 2013 r. 5,34 mld PLN (na koniec 2014 roku było to 5,47 mld PLN). Biorąc pod uwagę, że przeciętna wartość pożyczki udzielonej w sektorze pozabankowym w Polsce w 2013 r. wynosiła 449 PLN w wypadku pierwszej pożyczki oraz 745 PLN wobec klientów, którzy po raz kolejny korzystali z pożyczek, stąd liczba klientów korzystających z usług firm pożyczkowych jest szacowana na 3,5-4 mln osób. Chociaż firmy pożyczkowe w Polsce działają od kilkunastu lat, to ich rozkwit nastąpił po ostatnim światowym kryzysie finansowym, na skutek którego banki zaostrzyły wymogi dotyczące udzielania kredytów i pożyczek. Sytuację tę wykorzystały firmy pożyczkowe, oferując szybki dostęp do środków finansowych, bez uciążliwych formalności i bez szczegółowego weryfikowania zdolności kredytowej pożyczkobiorców. Z danych opracowanych przez Konferencję Przedsiębiorstw Finansowych wynika, że w latach 2009-2013 liczba udzielonych pożyczek przez podmioty zrzeszone w KPF wzrosła o 25\% (z 0,975 mln w 2009 r. do 1,23 mln w 2013 r.) $)^{22}$. $\mathrm{Z}$ drugiej strony, rozwój rynku firm pożyczkowych w Polsce to także efekt wypracowanego modelu biznesowego banków i rosnącego popytu na niskokwotowe i krótkoterminowe pożyczki, nieopłacalne z punktu widzenia banków. Tym samym nie można potwierdzić tezy, że rozwój firm pożyczkowych w Polsce odbywa się kosztem banków, ponieważ strategia działania banków opiera się w głównej mierze na sprzedaży jak największej liczby powiązanych ze sobą produktów generujących odsetki, prowizje i marże.

\footnotetext{
18 J. Ryba, Pożyczkowy rachunek sumienia, „Promeritum. Magazyn Związku Firm Pożyczkowych” 2015, nr 1 , s. 14

19 Diagnoza społeczna 2013. Warunki i jakość życia Polaków, red. J. Czapiński, T. Panek, Rada Monitoringu Społecznego, Warszawa 2013, s. 75

${ }^{20}$ KNF, Raport o sytuacji banków w Polsce 2013, Warszawa 2014.

${ }^{21} \mathrm{http}: / /$ issuu.com/zfp_/docs/promeritum_1_2015/4? e=15563906/11394912, dostęp 10.03.2015.

22 Sektor firm pożyczkowych w Polsce. Raport $z$ badania ankietowego członków KPF. Lata 2008-2013, Konferencja Przedsiębiorstw Finansowych w Polsce, Gdańsk maj 2014, s. 10.
} 


\section{Rozwój rynku pożyczek pozabankowych w otoczeniu zerowych stóp procentowych}

O ile rynek kredytów jest rynkiem uregulowanym pod względem prawnym, o tyle rynek pozabankowych pożyczek, jako część polskiego rynku finansowego, pozostaje poza kontrolą nadzoru finansowego. W rezultacie pożyczkobiorcy, którzy w ocenie banków nie mają zdolności kredytowej i nie są w stanie skorzystać z pożyczek oraz kredytów bankowych, zmuszeni są do poszukiwania krótkoterminowych źródeł finansowania na rynku pozabankowym. Prowadzi to częstokroć do nieuczciwych praktyk stosowanych przez firmy pożyczkowe, które w praktyce stosują lichwę. Pomimo ustalenia maksymalnego oprocentowania kredytów i pożyczek, w wielu krajach rzeczywiste roczne oprocentowanie kredytów sięga średnio kilkuset procent. Pożyczkobiorcy wpadają więc w spiralę zadłużenia, przed którą ustawodawcy nie są w stanie ich uchronić.

Z danych Banku Światowego wynika, że 76 państw na świecie stosuje regulacje prawne ograniczające wysokość oprocentowania kredytów i pożyczek ${ }^{23}$. Głównym powodem, dla którego wprowadzono w tych krajach limity oprocentowania kredytów i pożyczek jest przede wszystkim ochrona konsumentów przed nadmiernym, lichwiarskim oprocentowaniem, ograniczenie stopnia wykluczenia finansowego i uczynienie pożyczek bardziej dostępnymi dla niezamożnych gospodarstw domowych. W 28 krajach wysokość oprocentowania regulują przepisy ustawy o przeciwdziałaniu lichwie, w 24 krajach wysokość oprocentowania wynika z przepisów ustaw o koszcie kredytów i pożyczek. W pozostałych krajach wysokość oprocentowania jest ustalana poprzez rekomendacje właściwych urzędów. Tylko w Danii oraz Austrii nie ma prawnie uregulowanego maksymalnego oprocentowania dla kredytów i pożyczek. W ujęciu światowym podmiotem odpowiedzialnym za ustalenie limitu oprocentowania kredytów i pożyczek jest zazwyczaj bank centralny, ale także może nim być sąd, zgromadzenie ustawodawcze, parlament lub minister finansów.

Wysokość maksymalnego oprocentowania podawana jest w trzech formach:

- efektywna stopa procentowa - czyli oprocentowanie uwzględniające wszystkie koszty finansowe, takie jak odsetki, opłaty, prowizje, koszty ubezpieczenia itp.; efektywne oprocentowanie kredytów i pożyczek jest podawane w Tunezji, Zambii, Kamerunie, Republice Środkowej Afryki, Czadzie, Republice Kongo, Gwinei Równikowej, Gabonie, Beninie, Mali, Republice Nigru, Senegalu i Togo,

${ }^{23}$ S.M. Maimbo, C.A.H. Gallegos, Interest Rate Caps around the World. Still Popular, but a Blunt Instrument, Policy Research Working Paper WPS7070, World Bank Group, October 2014, s. 6. 
- roczna stopa procentowa - czyli efektywna stopa procentowa mnożona przez liczbę okresów kapitalizacji w roku; limity oprocentowania kredytów i pożyczek wg tej stopy podawane są w Belgii, Francji, Niemczech, Grecji, Irlandii, Włoszech, Holandii, Portugalii, Hiszpanii, Szwajcarii, Wielkiej Brytanii, Estonii, Słowacji, Słowenii i w Australii,

- nominalna stopa procentowa - nieuwzględniająca opłat, prowizji i innych kosztów; limity oprocentowania kredytów i pożyczek wg tej metody są podawane w Polsce, Chile, Kolumbii, Grecji, Indiach i w Republice Kirgistanu.

W większości krajów maksymalne oprocentowanie kredytów i pożyczek opiera się na efektywnej stopie procentowej lub rocznej stopie procentowej. Rzadziej stosuje się nominalne oprocentowanie. $Z$ punktu widzenia interesów pożyczkobiorcy kluczowe jest informowanie o łącznym koszcie zaciągnięcia pożyczki. $Z$ badań przeprowadzonych w 2013 r. przez Federację Konsumentów wynika, że 51,50\% pożyczkobiorców uwzględnia całkowity koszt kredytu lub pożyczki, 48,5\% ankietowanych zwraca uwagę na niskie oprocentowanie przy zaciąganiu kredytu lub pożyczki, 22,44\% klientów banków lub firm pożyczkowych uwzględnia wysokość prowizji, $15,46 \%$ uwzględnia RRSO ${ }^{24}, 13,22 \%$ badanych zwraca uwagę na opłaty wstępne, a $4 \%$ pożyczkobiorców nie stosuje żadnego kryterium oceny przy wyborze firmy pożyczkowej lub banku ${ }^{25}$. Wyniki tych badań wskazują na niski poziom świadomości finansowej klientów korzystających z szeroko dostępnej oferty krótkoterminowych pożyczek. Skoro tylko co drugi pożyczkobiorca zwraca uwagę na łączny koszt pożyczki i co szósty pożyczkobiorca zwraca uwagę na RRSO, nie powinno dziwić, czemu tak wiele osób wpada w spiralę zadłużenia (wg danych Związku Firm Pożyczkowych około $40 \%$ pożyczkobiorców ma problemy $\mathrm{z}$ terminowym regulowaniem zobowiązań wobec firm pożyczkowych ${ }^{26}$ ). Z badań przeprowadzonych przez PwC w $2013 \mathrm{r}$. wynika, że RRSO ${ }^{27}$ dla pożyczek udzielanych na okres do 1 tygodnia przekracza kilkadziesiąt tysięcy procent; dla pożyczek udzielanych na okres do 20 tygodni wynosi 1000-1200\%; dla pożyczek udzielanych na okres 30-40 tygodni wynosi 650-700\%; dla pożyczek udzielanych na okres ponad 50 tygodni wynosi około $300 \%$. Wpływ na tak wysokie RRSO ma przede wszystkim udział opłat stałych w łącznym koszcie pożyczek. Przykładowo, opłaty za obsługę domową pożyczki wynoszą $42 \%$ kwoty

\footnotetext{
${ }^{24}$ RRSO jest to całkowity koszt kredytu (suma wszelkich kosztów, jakie musi ponieść konsument w związku z umową o kredyt np. odsetek, prowizji, opłat), wyrażony jako wartość procentowa całkowitej kwoty kredytu w stosunku rocznym.

${ }^{25}$ Raport $z$ badania ankietowego Konsument na rynku ustug pożyczkowych, Federacja Konsumentów, Warszawa grudzień 2013, s. 11.

${ }^{26} \mathrm{~J}$. Ryba, Raport Mikropożyczki w Polsce. Pierwsze Badanie produktów, kosztów i obstugi pożyczek internetowych, Związek Firm Pożyczkowych, Warszawa 2013, s. 13.

27 Rynek firm pożyczkowych w Polsce, PwC, Warszawa 2013, s. 26.
} 
netto udzielonej pożyczki i 56\% całkowitych jej kosztów ${ }^{28}$. Przykładowe koszty pożyczek zaciąganych na okres 30 dni po raz kolejny (w większości firm pożyczkowych pierwsza pożyczka jest „bez opłat”) zostały zaprezentowane w tabeli 1.

Tabela 1. Koszt pożyczek (zaciąganych po raz drugi) na okres $30 \mathrm{dni}$ w wybranych firmach pożyczkowych oraz w dwóch bankach wg stanu na 23.03.2015

\begin{tabular}{|c|c|c|c|c|c|c|}
\hline Firma & Kwota & Prowizja & $\begin{array}{c}\text { Kwota do } \\
\text { splaty }\end{array}$ & RRSO & $\begin{array}{c}\text { Koszty } \\
\text { prolongaty }\end{array}$ & $\begin{array}{l}\text { Koszty powiadomień } \\
\text { w przypadku opóźnienia } \\
\text { spłaty }\end{array}$ \\
\hline Szybka gotówka & 1000PLN & 289,80 PLN & 1289,00 PLN & $2112 \%$ & $\begin{array}{l}7 \mathrm{dni}-70 \text { PLN } \\
14 \mathrm{dni}-140 \text { PLN } \\
30 \mathrm{dni}-280 \text { PLN }\end{array}$ & $\begin{array}{l}\text { SMS 5 PLN, e-mail 10PLN, } \\
\text { telefon 15 PLN, list polecony } \\
\text { 25 PLN; powiadomienie po 6, } \\
\text { 12, 18, } 24 \text { dniach każde } \\
\text { po 60 PLN a po } 30 \text { dniach } \\
\text { 70 PLN + odsetki ustawowe } \\
\text { (10\%) }\end{array}$ \\
\hline Wonga & $750 \mathrm{PLN}$ & 218,32PLN & 968,32 PLN & $2045 \%$ & $\begin{array}{l}\text { Brak możliwości } \\
\text { prolongowania }\end{array}$ & $\begin{array}{l}\text { Do 3. dnia po terminie } \\
\text { 40 PLN; od } 4 \text { do } 31 \text { dnia } \\
\text { po terminie 130 PLN; } \\
\text { powiadomienie: SMS } \\
\text { 3PLN, e-mail 2PLN; telefon } \\
\text { 35PLN; list 10PLN + odsetki } \\
\text { ustawowe (10\%) }\end{array}$ \\
\hline Lendon.pl & 1000PLN & 284,00 PLN & 1284,00 PLN & $1994 \%$ & $\begin{array}{l}7 \text { dni - 176PLN } \\
14 \text { dni 224PLN } \\
30 \text { dni - 288PLN }\end{array}$ & $\begin{array}{l}\text { Opłata za przygotowanie } \\
\text { powiadomienia 40 PLN; } \\
\text { pierwszy monit 140PLN; } \\
\text { drugi monit 120 PLN, trzeci } \\
\text { i czwarty monit 80 PLN; } \\
\text { piąty monit 60 PLN + odsetki } \\
\text { ustawowe }(10 \%)\end{array}$ \\
\hline Filarum.pl & 1000PLN & 281,08PLN & 1281,08PLN & $1936 \%$ & $\begin{array}{l}7 \mathrm{dni}-150 \text { PLN } \\
14 \mathrm{dni}-200 \text { PLN } \\
30 \mathrm{dni}-300 \text { PLN }\end{array}$ & $\begin{array}{l}\text { 5PLN za każdy SMS } \\
\text { (maks. } 4 \text { SMS-y) + odsetki } \\
\text { ustawowe }\end{array}$ \\
\hline $\begin{array}{l}\text { SMART } \\
\text { pożyczka.pl }\end{array}$ & 1000PLN & 234,00PLN & 1234,00 PLN & $1191 \%$ & $\begin{array}{l}7 \mathrm{dni}-179 \text { PLN } \\
14 \mathrm{dni}-229 \text { PLN } \\
30 \mathrm{dni}-282 \text { PLN }\end{array}$ & $\begin{array}{l}8 \text { powiadomień SMS } \\
\text { po 4,5 PLN każdy; } \\
2 \text { powiadomienia e-mail } \\
\text { po 4,5 PLN każdy; } \\
3 \text { powiadomienia listem } \\
\text { poleconym 29 PLN każdy; } \\
1 \text { powiadomienie listem } \\
\text { poleconym } 59 \text { PLN + odsetki } \\
\text { ustawowe }\end{array}$ \\
\hline $\begin{array}{l}\text { Bank SMART } \\
\text { (Mikropożyczka) }\end{array}$ & 1000PLN & 395,00PLN & 1395,00 PLN & $1333,65 \%$ & $\begin{array}{l}\text { Brak możliwości } \\
\text { prolongowania }\end{array}$ & $\begin{array}{l}\text { 15PLN za monity wysyłane } \\
20,33 \text { i } 48 \text { dnia po terminie } \\
\text { spłaty + odsetki ustawowe } \\
(10 \%)\end{array}$ \\
\hline $\begin{array}{l}\text { PKO BP SA } \\
\text { (Mini Ratka) }\end{array}$ & 1000PLN & 207,00PLN & 1207,00 PLN & $1014,14 \%$ & $\begin{array}{l}\text { Brak możliwości } \\
\text { prolongowania }\end{array}$ & Odsetki ustawowe (10\%) \\
\hline
\end{tabular}

Źródło: Opracowanie na własne na podstawie danych analizowanych instytucji.

\footnotetext{
${ }^{28}$ Ibidem, s. 27
} 
Pierwszym bankiem w Polsce, który zdecydował się pod koniec października 2014 r. na rozszerzenie swojej oferty o tzw. chwilówki, był mobilny Bank SMART, będący częścią FM Bank PBP SA ${ }^{29}$. Kwota pierwszej Smart Mikropożyczki wynosi od 100 do 1000 PLN, zaś kolejnej pożyczki do 1200 PLN. Maksymalny termin, na jaki jest udzielana pożyczka wynosi 30 dni. Klient składa wniosek online, a środki trafiają na rachunek klienta w ciągu 15 minut od złożenia wniosku. Warunkiem przyznania pożyczki, która ma formę nieodnawialnego limitu w rachunku, jest posiadanie ROR w Banku SMART. Wnioskodawca jest weryfikowany w bazach danych o klientach i musi dokonać przelewu autoryzacyjnego z innego rachunku bankowego. Bank nie wymaga przedstawienia dodatkowych zaświadczeń. Wnioskodawca ma prawo do jednej pożyczki, a o kolejną może wnioskować po spłacie pierwszej. Roczne oprocentowanie nominalne tej chwilówki wynosi $6 \%$. Koszty prowizji $7 \%$ od udzielonej kwoty pożyczki. Koszty obsługi pożyczki wynoszą $6,5 \%$, zaś koszty oceny zdolności kredytowej wynoszą 6\%. Za każdy pożyczony 1000 PLN klient płaci 200 PLN $^{30}$. Dodatkowo, w wypadku nieterminowego regulowania należności, klient ponosi koszty w wysokości czterokrotności stopy lombardowej NBP. W tabeli 1 uwzględniono także w celach porównawczych ofertę PKO BP SA dla kredytu Mini Ratka, który de facto nie ma charakteru kredytu chwilowego, lecz zwykłego kredytu konsumpcyjnego, dla którego minimalny okres spłaty wynosi 3 lata. Dane te pokazują jednak, że pomimo obowiązujących limitów oprocentowania kredytów konsumpcyjnych, zarówno banki, jak i firmy pożyczkowe omijają ustawowe zapisy i maksymalizują swoje zyski, częstokroć kosztem nieświadomych klientów.

Ponieważ w Polsce maksymalny limit odsetek ${ }^{31}$ jest regulowany zapisem art. 359 $\$ 2^{1}$ k.c. (tekst jedn. Dz. U. 2014, poz. 121), stąd też firmy pożyczkowe, celem ominięcia tego zapisu, stosują zerowe oprocentowanie na rzecz wprowadzenia obowiązkowych opłat i prowizji związanych z udzieleniem pożyczki. Według stanu na 20 marca 2015 r. stopa lombardowa wynosiła 2,5\%, stąd też maksymalne oprocentowanie nie mogło przekraczać $10 \%$. Jednakże w porównaniu do łącznego kosztu pożyczek, ten wprowadzony limit nie przekłada się na całkowity koszt płacony przez pożyczkobiorcę. Zarówno banki, jak i firmy pożyczkowe omijają ten zapis i zarabiają

${ }^{29}$ Największym akcjonariuszem banku jest fundusz private equity Abris Capital Partners, którego głównymi inwestorami są: AP 2 Swedish National Pension Fund, BNP Paribas Private Equity, Harvard Management Company, John's Hopkins University, Nordea Bank, University of North Carolina Management Company, University of Pittsburg oraz VER - State Pension Fund of Finnland.

${ }^{30} \mathrm{http}: / /$ www.banksmart.pl/download/mikropozyczka/TOOiP-SMART-mikropozyczka.pdf, dostęp 10.03.2015.

${ }^{31}$ Maksymalna wysokość odsetek wynikających z czynności prawnej nie może w stosunku rocznym przekraczać czterokrotności wysokości stopy kredytu lombardowego Narodowego Banku Polskiego (odsetki maksymalne). 
na opłatach dodatkowych związanych z udzieleniem kredytu lub pożyczki. Zatem wysokość podstawowych stóp procentowych banku centralnego nie wpływa w sposób bezpośredni na rozwój pozabankowego rynku pożyczek w Polsce. Od 2009 r. maksymalne ustawowe oprocentowanie kredytów i pożyczek zmalało z 26\% do 10\% (wg stanu na 20 marca 2015 r.). W tym samym czasie średnie oprocentowanie kredytów konsumpcyjnych dla gospodarstw domowych zmalało z 16\% w styczniu 2009 r. do $10,4 \%$ w styczniu 2015 r. (rysunek 1).

\section{Rysunek 1. Porównanie średniego oprocentowania kredytów konsumpcyjnych dla gospodarstw domowych na rynku regulowanym $\mathrm{z}$ maksymalnym ustawowym oprocentowaniem kredytów i pożyczek w Polsce w okresie styczeń 2009-styczeń 2015}

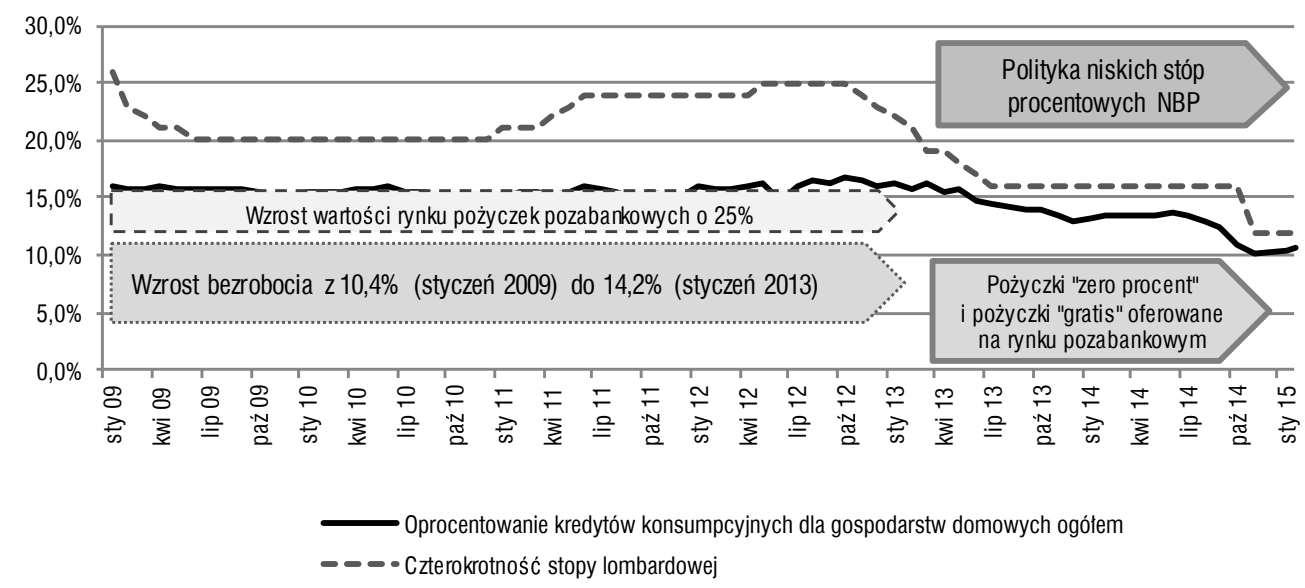

Źródło: Opracowanie własne na podstawie danych NBP.

Dynamiczny rozwój rynku pożyczek pozabankowych odbywał się w otoczeniu rosnącej stopy bezrobocia, które wzrosło z 10,4\% w styczniu 2009 r. do $14,2 \%$ w styczniu 2013 r. W momencie wejścia przez RPP w fazę realizowania polityki niskich stóp procentowych firmy pożyczkowe zmieniły strategię marketingową, reklamując swoje produkty jako pożyczki „zero procent” lub oferując pierwszą pożyczkę „gratis". Realizowana w Polsce polityka niskich stóp procentowych wykazuje ograniczoną skuteczność w zakresie oddziaływania na całkowity koszt pożyczek i kredytów zarówno na rynku bankowym, jak i pozabankowym. Obniżanie podstawowych stóp procentowych przez banki centralne, przy optymistycznych przewidywaniach rozwoju koniunktury gospodarczej, przekłada się na wzrost akcji kredytowej dla przedsiębiorstw średnio po 4-6 kwartałach. Szczególnie jest to widoczne w Polsce, gdzie obniżka stóp procentowych przez bank centralny, nawet o niewiele punktów 
bazowych, niemalże natychmiast powoduje obniżenie przez banki komercyjne oprocentowania depozytów, ale nie kredytów. Nie przekłada się to jednak w bezpośredni sposób na maksymalny koszt pożyczki na rynku pozabankowym. Ponieważ pierwsze obniżki stóp procentowych banku centralnego, przekładające się na wzrost akcji kredytowej, widoczne są najwcześniej po kilkunastu miesiącach, stąd też RPP powinna zdecydować o głębszej obniżce już na początku $2010 \mathrm{r}$. W polskiej gospodarce silnie odczuwany był spadek popytu w tym okresie, stąd też istniała potrzeba obniżenia ceny pieniądza już na początku drugiej dekady XXI w. Ten stan został bardzo dobrze wykorzystany przez firmy pożyczkowe działające na rynku nieregulowanym, które potrafiły sprzedać po wysokiej cenie swój pieniądz częstokroć nieświadomym klientom wykluczonym przez sektor bankowy. Decyzje RPP przekładają się przede wszystkim na dostęp do pieniądza i koszt kredytu - im wyższe stopy, tym trudniejszy dostęp do finansowania i droższe kredyty bankowe. Spadające stopy obniżają cenę pieniądza, powodują, że kredyt jest tańszy i teoretycznie bardziej dostępny, a to z kolei powinno pobudzać konsumpcję i inwestycje przedsiębiorstw. Zaimplementowana w Polsce odpowiednio wcześniej polityka niskich stóp procentowych byłaby korzystna dla wszystkich kredytobiorców, zarówno dla gospodarstw domowych, jak i dla poszukujących krótkoterminowych pożyczek klientów rynku pozabankowego.

\section{Podsumowanie}

Współczesny kształt pozabankowego rynku pożyczek jest wypadkową pięciu podstawowych zmiennych: procesu legislacyjnego i istniejących uregulowań prawnych, decyzji Rady Polityki Pieniężnej i wiążącej się z tym wysokości stopy lombardowej, poziomu zamożności i świadomości finansowej społeczeństwa oraz dostępności usług i produktów bankowych. W 2014 r. rozpoczęły się w Ministerstwie Finansów prace nad założeniami projektu ustawy $\mathrm{O}$ nadzorze nad rynkiem finansowym, ustawy Prawo bankowe oraz niektórych innych ustaw (projekt z 18 kwietnia 2014r.). Propozycje zmian dotyczą przeciwdziałania próbom obchodzenia ustawowo określonych limitów kosztów pozaodsetkowych oraz wprowadzenia maksymalnej wysokości odsetek za opóźnienie w spłacie i odsetek od odsetek. W procesie legislacyjnym usunięto niestety zapis o utworzeniu centralnego rejestru firm pożyczkowych, co z pewnością wpłynie na rozwój szarej strefy pożyczek. Przyjęta w niniejszym artykule metodyka badawcza pozwoliła pozytywnie zweryfikować hipotezę, mówiącą o tym, że brak nadzoru nad firmami pożyczkowymi działającymi na terenie Polski prowadzi do lichwiarskiego wyzysku tych, którzy zostali wykluczeni przez banki, skutkując wpadaniem przez 
tę grupę społeczeństwa w spiralę zadłużenia. Biorąc pod uwagę realizowaną w Polsce politykę stóp procentowych można stwierdzić, że zbyt późne wejście w fazę zdecydowanych obniżek podstawowych stóp procentowych banku centralnego przyczyniło się do rozwoju pozabankowego rynku pożyczek. Dla firm pożyczkowych decyzje RPP nie mają zasadniczego znaczenia, ponieważ podmioty te i tak omijały i nadal omijają ustawowy limit oprocentowania. Ich model działania opiera się na opłatach tzw. organizacyjnych, które windują RRSO krótkoterminowych pożyczek do kilku tysięcy procent. Pomimo najniższych w historii podstawowych stóp procentowych w Polsce nie zmienia się oferta firm pożyczkowych ani nie tanieje pożyczany przez te podmioty pieniądz, ponieważ one finansują swoją działalność ze środków własnych. Dzięki nadzwyczajnie wysokiej skuteczności w docieraniu do klientów firmy pożyczkowe dynamicznie się rozwijają i oferują alternatywne źródło zaspokajania potrzeb finansowych kilku milionów Polaków. Istnieje zatem wciąż pilna potrzeba objęcia nadzorem finansowym tych podmiotów i wzrostu transparentności ich działania. Równolegle należy czynić starania, by świadomość finansowa Polaków była nieustannie zwiększana.

\section{Bibliografia}

Awal R., Financial exclusion and Microcredit, Lambert Academic Publishing, 2011.

Diagnoza społeczna 2013. Warunki i jakość życia Polaków, red. J. Czapiński, T. Panek, Rada Monitoringu Społecznego, Warszawa 2013.

Directive 2008/48/EC of the European Parliament and of the Council of 23 April 2008 on credit agreements for consumers and repealing Council Directive 87/102/EEC. L133/66.

Dymski G., Financial Globalization, Social Exclusion and Financial Crisis, "International Review of Applied Economics" 2005, Vol. 19, No. 4.

Edukacja i świadomość finansowa, red. M. Iwanicz-Drozdowska, Oficyna Wydawnicza SGH, Warszawa 2011.

Eseje o stabilności finansowej. Ksiegga jubileuszowa. 45 lat pracy naukowej prof. $z w . d r$. hab. Bogusława Pietrzaka, red. A. Alińska, CeDeWu, Warszawa 2012.

European Social Statistics, 2013 edition. Eurostat pocketbooks s. 172, http://ec.europa. eu/eurostat/documents/3930297/5968986/KS-FP-13-001-EN.PDF/6952d836-71254ff5-a153-6ab1778bd4da, European Commission, dostęp 15.03.2015.

Financial Services Provision and Prevention of Financial Exclusion, European Commission, Brussels May 2008. 
Lenton P., Mosley P., Financial Exclusion and the Poverty Trap. Overcoming deprivation in the inner city, Routledge 2012.

Leyshon A., Thrift N., Money/Space. Geographies of Monetary Transformation, Routledge, London 1995.

Lister R., Bieda, Sic, Warszawa 2007.

Loyalty Benchmark, PBS, 2012, http://pbs.pl/x.php/1,1072/Wskaznik-ubankowienia-Polakow-zwalnia.html, dostęp 10.03.2015.

Maimbo S.M., Gallegos C.A.H., Interest Rate Caps around the World. Still Popular, but a Blunt Instrument, Policy Research Working Paper WPS7070, World Bank Group, October 2014.

Marcinkowska M., Kuchciak I., Świeszczak M., Świeszczak K., Edukacja finansowa i inkluzja bankowa $w$ realizacjach koncepcji silver economy, Wydawnictwo Uniwersytetu Łódzkiego, Łódź 2014.

McKean L., Lessem S., Bax E., Money Management by Low-income Households: Earning, Spending, Saving, and Accessing Financial Services, Center for Impact Research, August 2005, http://www.impactresearch.org/documents/FirstAccountsExecutiveSummary. pdf, dostęp 10.03.2015.

New Frontiers in Banking Services. Emerging Needs and Tailored Products for Untapped Markets, red. L. Anderloni, M.D. Braga, E.M. Carluccio, Springer-Verlag BerlinHeidelberg 2007.

Panek T., Ubóstwo, wykluczenie społeczne i nierówności. Teoria i praktyka pomiaru, Oficyna Wydawnicza SGH, Warszawa 2011.

Panek T., Zwierzchowski J., Porównawcza analiza sfery ubóstwa $w$ krajach UE $w$ ujęciu regionalnym, „Zeszyty Naukowe Instytutu Statystyki i Demografii SGH” 2013, nr 35.

Raport o sytuacji banków w Polsce 2013, KNF, Warszawa 2014.

Raport z badania ankietowego Konsument na rynku uslug pożyczkowych, Federacja Konsumentów, Warszawa 2013.

Ryba J., Pożyczkowy rachunek sumienia, „Promeritum. Magazyn Związku Firm Pożyczkowych" 2015, nr 1.

Ryba J., Raport Mikropożyczki w Polsce. Pierwsze Badanie produktów, kosztów i obstugi pożyczek internetowych, Związek Firm Pożyczkowych, Warszawa 2013.

Rynek firm pożyczkowych w Polsce, PwC, Warszawa 2013.

Santiago C., Gardener E.P.M., Molyneux P., Financial Exclusion, Palgrave Macmillan, 2005.

Sektor firm pożyczkowych $w$ Polsce. Raport $z$ badania ankietowego członków KPF. Lata 2008-2013, Konferencja Przedsiębiorstw Finansowych w Polsce, Gdańsk maj 2014.

Szopa B., Szopa A., Wykluczenie finansowe a wykluczenie społeczne, „Zeszyty Naukowe Polskiego Towarzystwa Ekonomicznego" 2011, nr 11. 
Ubóstwo i wykluczenie społeczne - perspektywa poznawcza, red. Szarfenberg R., Żołędowski C., Theiss M., Dom Wydawniczy ELIPSA, Warszawa 2010.

ZBP, Polityka kredytowa w Polsce i w UE, Związek Banków Polskich, lipiec 2014, http://zbp. $\mathrm{pl} /$ public/repozytorium/wydarzenia/images/lipiec_2014/Konferencja_Prasowa/ZBP_ Raport_polityka_kredytowa_w_Polsce_i_UE.pdf, dostęp 10.03.2015.

Zwyczaje płatnicze Polaków, NBP, Warszawa 2013.

\section{Payday Lending Market in Poland and the Central Bank's Low Interest Rate Policy}

A large part of the society is still financially excluded from social life despite the era of low or zero interest rates. Banks are not interested in rendering services to customers of limited means. In consequence, citizens excluded from the banking sector are searching for the alternative sources to satisfy their financial needs. Money is supplied by payday loan providers which offer usurious short term loans at prices many times higher than bank prices. The article answers the following research question: Is the payday lending market winning the competition with the banking sector in Poland and if so, what is the reason in era of historic low basic interest rates and incomparably higher total costs of payday loans? The following research hypothesis was verified in the study: the lack of supervision over payday loan companies in Poland contributes to usurious exploitation of the people excluded by banks, which results in a debt spiral for a considerable segment of customers.

Keywords: payday loans, usury, financial exclusion, low interest rate policy

\section{Le marché des prêts sur salaire en Pologne et la politique de taux d'intérêt bas de la Banque centrale}

Une grande partie de la société polonaise est toujours financièrement exclue de la vie sociale malgré vivre à une époque des taux d'intérêt bas ou nuls. Les banques ne sont pas intéressées à rendre des services à des clients avec des moyens financiers limités. En conséquence, les citoyens exclus du secteur bancaire sont à la recherche pour les sources alternatives afin de satisfaire leurs besoins financiers. La solution est proposée par les fournisseurs des prêts sur salaire qui offrent des prêts à court 
terme usuraires à des prix beaucoup plus élevés que les prix des banques. L'article répond à la question de recherche suivante: est-ce que le marché des prêts sur salaire est plus compétitif que le secteur bancaire en Pologne et si oui, quelle est la raison? L'hypothèse suivante a été vérifiée dans l'étude: le manque de contrôle sur les sociétés de prêt sur salaire en Pologne contribue à l'exploitation usuraire des personnes exclues par les banques, et en conséquence à la spirale de la dette pour de nombreux clients.

Mots-clés: les prêts sur salaire, l'usure, l'exclusion financière, la politique de taux d'intérêt bas

\section{Рынок займов до зарплаты в Польше в контексте ведения центральным банком политики низких процентных ставок}

Несмотря на эпоху низких или нулевых процентных ставок, большая часть общества по-прежнему остается исключенной из финансовой сферы общественной жизни. Банки не заинтересованы в оказании услуг клиентам с ограниченными средствами. В результате того, граждане, исключены из банковского сектора, ищут альтернативные способы удовлетворения своих финансовых потребностей. Поставщиком денег являются компании, которые предлагают краткосрочные ссуды по ценам во много раз выше, чем в банке. Целью статьи является ответ на следующий вопрос: Является ли рынок займов до зарплаты выигрышным в отношении банковского сектора в Польше, и если да, то почему, учитывая исторически низкие базовые процентные ставки и несравненно более высокую стоимость займа? Исследование подтвердило следующую гипотезу: отсутствие надзора в Польше над кредитными компаниями, предлагающими займы до зарплаты, приводит к ростовщической эксплуатации тех, кто исключен банками, и, в результате, к попаданию значительной части этой группы в спираль задолженности.

Ключевые слова: займы до зарплаты, ростовщичество, финансовая изоляция, политика низких процентных ставок 
